\title{
ANALYZING TECHNOLOGY ACCEPTANCE FOR INTERNET OF THINGS (IOT) AMONG ACCOUNTING AND FINANCE STUDENTS
}

\author{
DOI: 10.17261/Pressacademia.2019.1163 \\ JBEF- V.8-ISS.4-2019(2)-p.198-208
}

\author{
Nurgün Komsuoglu ${ }^{1}$ Yilmaz, Hulya Boydas Hazar ${ }^{2}$ \\ ${ }^{1}$ Istanbul Aydin University, Department of Business Administration, Sefakoy, Istanbul, Turkey. \\ nurgunyilmaz@aydin.edu.tr, ORCID: 0000-0002-9050-9796 \\ ${ }^{2}$ Istanbul Aydin University, Department of Business Administration, Sefakoy, Istanbul, Turkey. \\ hulyahazar@aydin.edu.tr, ORCID: 0000-0002-7115-1899
}

Date Received: November 10, 2019

Date Accepted: December 20,2019

To cite this document

Yilmaz, N.K., Hazar, H.B., (2019). Analyzing technology acceptance for internet of things (lot) among accounting and finance students. Journal of Business, Economics and Finance (JBEF), V.8(4), p.198-208.

Permemant link to this document: http://doi.org/10.17261/Pressacademia.2019.1163

Copyright: Published by PressAcademia and limited licenced re-use rights only.

\begin{abstract}
Purpose- The purpose of this study is to test technology acceptance model for internet of things (loT) among accounting and finance students. Internet of things refers the interconnection between devices via internet including mechanical and digital objects. The advancements in internet technology, wireless communication, microelectromechanical systems (MEMS) and radio frequency identification (RFID) created a world of interconnected devices. The term loT is used in conjunction with all the devices that send data to each other, including appliances which are used in our daily lives. Since loT has a wide range of use in Finance and Accounting, its acceptance among accounting and finance students is important.

Methodology- In this study, a quantitative research has been conducted by using survey method. In this research, following a literature review, technology acceptance of IoT among Accounting and Finance students have been tested by using appropriate statistical techniques.

Findings- Findings of the study imply that there is positive correlation between research variables. This result shows that participants are ready to accept technological developments in loT.

Conclusion- As a result of the study, it is tested technology acceptance among accounting and finance students for Internet of Things (loT). The technological advancements in loT increase the level of automation and have a wide range of usage in accounting and finance, primarily in banking. Therefore, its level of acceptance between accountants and finance managers is important.
\end{abstract}

Keywords: Technology acceptance model, internet of things (loT), finance, accounting

JEL Codes: L68, G10, M41

\section{INTRODUCTION}

With the recent advancements, a new technology called Internet of Things (IoT) which is simply an interconnected network of many different types of devices gained great importance with its wide range of use. This network covers from huge computerized production machines in factories to everyday use home devices like refrigerators. By using this intercommunication-based technology between devices, many novelties and conveniences come to human and work life. By using loT everyday devices may collect usage data at home and can share it with their counterparts. Refrigerators may check their stock levels and automatically order products. Beds may use MEMS sensors and may ask you to use new clean sheets because of bacteria level. Wide spreading broadband internet, faster wireless connections, RFID enabled devices, more useful MEMS chips and many other technological advancements support loT technology. The Internet of Things simplifies the management of workflow in production areas, reduces costs during storage, material tracking and distribution, and increases efficiency by saving time. Internet of things provides data to be collected in a pool to provide more accurate results in the analysis of data. The Internet of Things is not only used in supply chain and production management, but also in finance, banking, payments and accounting issues. 
Similarly, with other sectors, product diversity, customer satisfaction and customer-specific products in the finance sector will prevent the customer from choosing another bank, especially in the banking sector. Banking transaction security, accurate information flow and speed are important in financial services. With the rapid development of technology, the use of mobile devices in the banking sector, the use of face recognition systems that are safer than the PIN code used in ATM transactions, and the creation of wearable credit card systems contributed to the speed and security of the banking system. Technology Acceptance Model (TAM) is created by (Davis, 1989) to be able to predict users' level of acceptance for computers. In this study, it is examined technology acceptance level of accounting and finance students for Internet of Things. It is perceived that the use of this new technology is gaining importance day by day for both disciplines. This study is based on the preliminary proceeding of Komsuoglu Yilmaz \& Boydas Hazar (2019) titled "The Rise of Internet of Things (IoT) and Its Applications in Finance and Accounting" presented in 9th Istanbul Finance Congress, and its purpose is to test technology acceptance model for internet of things (IoT) among accounting and finance students.

\section{LITERATURE REVIEW}

\subsection{Internet of Things (IOT)}

Internet of Things (IOT) is a relatively new concept. Two decades have passed since British technology pioneer Kevin Ashton used the words "Internet of Things-IoT" as a concept in a conference in Procter\&Gamble in 1999 (Ashton, 2009). In these 20 years, the concept has found huge area of interest both research and development side. Internet of Things (IoT) is transforming main communication form on the Internet: human to human (Tan \& Wang, 2010) to object to object form by providing interconnection between devices. As a new technology, the Internet of Things (IoT) creates a way to link objects and transfer data between them (Kumar \& Raza, 2017). This interconnection may have a huge impact on humans' lives. Internet of things provides new connection alternatives between "human to human", "human to object" and "object to object". These connection alternatives provide good opportunities not only for businesses but also everyday life. Refrigerators may understand that egg stock is low and order it from grocery store or automobiles may understand that they need maintenance and may take an appointment or coffeemakers may get a signal from your smartphones location services and understand that you headed to home and begin to prepare your coffee. It is expected that these changes will have a facilitating effect for everyday life of humans by providing them more spare time. In his study, (Stankovic, 2014) listed main research needs for Internet of Things as seen on Table 1.

Table 1: Research Needs on Internet of Things

\begin{tabular}{ll}
\hline Research Problem & Explanation \\
\hline Massive Scaling & $\begin{array}{l}\text { Since the number of devices increase, data usage and the need for wireless } \\
\text { networks will also increase. The management of the network formed by these } \\
\text { devices will pose a problem. }\end{array}$ \\
\hline Architecture and Dependencies & $\begin{array}{l}\text { Over connection to internet by millions of loT devices forces companies to } \\
\text { build better architectures. And with this architecture, connecting, controlling, } \\
\text { communicating and usage of the technology will be facilitated. }\end{array}$ \\
\hline Creating Knowledge and Big Data & $\begin{array}{l}\text { There is a continuous data collection with the technology. New data mining } \\
\text { techniques should be developed to deal with meaningful information. }\end{array}$ \\
\hline Robustness & $\begin{array}{l}\text { loT devices will locate other devices, will be in sync and cooperate with others } \\
\text { to do their daily routines. }\end{array}$ \\
\hline Openness & Data collection, data analysis and data use should work with openness. \\
\hline Security & $\begin{array}{l}\text { Wireless connection, RFID stickers, MEMS chips, GPS devices and software } \\
\text { used in loT makes security an issue to be concerned. Companies should create } \\
\text { new procedures to deal with security issues. }\end{array}$ \\
\hline Privacy & $\begin{array}{l}\text { The communication abilities of loT will have numerous benefits in aiding } \\
\text { people. However, security will be disregarded in many instances. Privacy } \\
\text { policies should be specified to prevent this. }\end{array}$ \\
\hline Humans in the Loop & As loT applications proliferate they will become more complicated. \\
\hline Resource: Stankovic J. A. (2014). Research Directions for The Internet of Things. IEEE Internet of Things Journal. \\
$\begin{array}{l}\text { On the table above, main concerns on Internet of Things can be seen. But these concerns are directly related to technology } \\
\text { itself and not its area of use. With a general classification, loT has two main users: Consumers and Businesses. Consumers } \\
\text { are using the technology to facilitate their daily lives and companies may use it for the same reason: facilitating their } \\
\text { procedures. }\end{array}$
\end{tabular}


Balakarthiga (2018) listed top seven applications of loT for business as follows:

\author{
- Revenue management \\ - Data management \\ - Inventory and maintenance management \\ - Customer services management \\ - Logistics management \\ - Enhancing customer experience \\ - Security management
}

Almost all business functions may be adapted with internet of things and create new business opportunities. By interconnecting devices and sensors, businesses may find the opportunity to conduct more efficient operations. Buyya \& Dastjerdi (2016) analyzed main principles and paradigms for internet of things. While Samaila, Neto, Fernandes, Freire, \& Inácio (2017) discussed security challenges, Weinberg, Milne, Andonova, \& Hajjat (2015) analyzed the subject with a privacy, secrecy and convenience window. Since the security is a primary issue on Internet of things Dorey (2017); Jing, Vasilakos, Wan, Lu, \& Qiu (2014); Riahi Sfar, Natalizio, Challal, \& Chtourou (2018); Sicari, Rizzardi, Grieco, \& Coen-Porisini (2015); Suo, Wan, Zou, \& Liu (2012); Weber (2010); Zhao \& Ge (2013) also conducted studies on this subject. In their study Caro \& Sadr (2019) examined the usage of IoT in balancing supply and demand. Mathaba, Adigun, Oladosu, \& Oki (2017) analyzed the synergy created by using two different technologies in inventory management: IoT and Web 2.0. In their study, Xu \& Chen (2016) examined the effect of solutions based on internet of things to improve just-in-time effectiveness. In the literature there are also many studies on IoT and logistics including Barreto, Amaral, \& Pereira (2017); Macaulay, Buckalew, \& Chung (2015); Sun (2012) and supply chain management including Ben-Daya, Hassini, \& Bahroun (2017); Haddud, DeSouza, Khare, \& Lee (2017); Tjahjono, Esplugues, Ares, \& Pelaez (2017); Verdouw, Wolfert, Beulens, \& Rialland (2016); Zhou, Chong, \& Ngai (2015). Bi, Xu, \& Wang (2014) examined the usage of loT on enterprise systems of modern manufacturing. Löffler \& Tschiesner (2013) discuss the future of manufacturing systems in the light of loT technologies. Shariatzadeh, Lundholm, Lindberg, \& Sivard (2016) discussed the transition period from digital factory to smart factory with IoT. Hasselblatt, Huikkola, Kohtamäki, \& Nickell (2018) have been modeled manufacturer's capabilities for the internet of things. Willner, (2018) made an analysis on the industrial usage of loT. Storey (2014) also made a research on industrial loT. Lee \& Lee (2015) investigated loT investment opportunities and challenges for companies. In their study Haller, Karnouskos, \& Schroth (2009) analyzed internet of things with an industrial perspective and provided its business value as an investment alternative. Perera, Liu, Jayawardena, \& Chen (2015) conducted a survey to see loT with an industrial market perspective.

\title{
2.2. Importance of loT for Accounting and Finance
}

Industry 4.0 is a revolution in the industry by using technology and artificial intelligence together and reflecting it into our lives, especially in the production process. Almost all business functions may be adapted with internet of things and create new business opportunities. As a revolution, Industry 4.0 transformed all devices from their shape to their hardware (Gürün, 2019). By interconnecting devices and sensors, businesses may find the opportunity to conduct more efficient operations. Technology, artificial intelligence and the Internet of things are main advancements related to Industry 4.0. With the use of these innovations, information can be gathered in a pool to be analyzed. Thus, defective production can be reduced, and time and cost savings obtained. Industry 4.0 is envisaged to increase productivity and efficiency. High technology applications related concepts not only concern the production process, but also enable efficient work in finance and accounting issues.

Uses of loT in Banking may provide the attributes seen in Table 2 below. 
Table 2: loT and Banking

\begin{tabular}{ll}
\hline Wealth management personalization & $\begin{array}{l}\text { It is related to the accurate and fast data collection, which creates } \\
\text { better insights. }\end{array}$ \\
\hline Improved payment security & $\begin{array}{l}\text { By using internet of things, new forms of payment tools-including } \\
\text { smart cards, biometric tokens, and more can be created. }\end{array}$ \\
\hline Transaction automation & $\begin{array}{l}\text { Ensures that security and control of transactions can be done from a } \\
\text { single place. }\end{array}$ \\
\hline Improved transparency & $\begin{array}{l}\text { In the future, for banks, loT means that credit providers will be } \\
\text { provided with detailed customer data: credit debt and history, asset } \\
\text { details and value, as well as commodity yields produced by the } \\
\text { client. }\end{array}$ \\
\hline Optimized capacity management & $\begin{array}{l}\text { Considering the customer numbers visiting the bank, the number of } \\
\text { workers per customer optimization is made. }\end{array}$ \\
\hline Voice assistants & $\begin{array}{l}\text { IoT will facilitate banks embrace voice-driven communications. } \\
\text { Operations can be performed by the customer himself without the } \\
\text { need for an intermediary. }\end{array}$ \\
\hline Resource: Created by using the information on https://www.digiteum.com/internet-of-things-banking-finances
\end{tabular}

Another challenge is to create new accounting models which can incorporate information coming from sensors of billions of devices. IoT has changed the way business is done today. IoT led to advancements in the accounting discipline as well. Internet of things may help the accounting professionals in the following areas:

Table 3: loT Technology for Accountants

Providing Data for Business Models

Asset Management

Inventory Management
The IoT can provide an abundant amount of past and present data. This provides data to business models for decision making. Past data is needed to form models and to correct them.

IoT always allows businesses to know the whereabouts of their assets. The information system may alert when maintenance is needed on any of the assets. This enables better planning and resource allocation.

Smart storage allows businesses to know where the inventory is stored at all times. Moreover, it gives a correct count of the inventory. Instead of manually counting inventory at certain times, it is possible to know its quantity precisely at a given time. When an inventory is below a certain level, the accounting software can automatically reorder it directly from a supplier. This helps inventory management and enables to use resources more efficiently.

IoT does not only help to track inventory in the warehouse but makes it possible to track the shipments worldwide. RFID chips can be integrated to products to keep tabs of the current status and other information about the shipment (Rathore, 2019).

The cost of materials is a fundamental component of the product cost. loT can assist businesses to get better price quotes on materials. Moreover, information on inventory transportation, time needed to supply the materials and other relevant information help to calculate the cost more accurately.

Billing Services $\quad$ Since loT connects devices on a global scale, it is suitable to automate invoicing and billing services. Accounting systems of customers and suppliers can be connected to automate the billing services.

Auditing Audits are time consuming for the accounting team. Accountants are expected to gather all the related documents and compile them in an order so that the financial information is ready for the auditors to check. Since all ledgers are connected in loT, sorting transactions will not take too much effort and time (Rathore, 2019). This would decrease the stress on the accounting team. When loT technology is used in accounting, it is expected that high volumes of data and transactions are processed. It is imperative that this data is audited. The classical auditing method of sampling leaves out large quantities of transactions unaudited. This increases the possibility of not finding anomalies in the data during audits. Moreover, most of the data captured by loT 
is in real time. Computer aided audit tools and techniques can be used to audit the full audit domain. Continuous auditing technique can be implemented to make audits in real time.

Budgeting loT technology improves the budgeting process. The information received from many networks helps the planning and forecasting stages of budgeting (Chandi, 2017). The forecasting models can be tested and refined using the versatile and generous amount of data. This increases the predictive ability of the forecasting model.

Providing Advice to Clients The accountant's role has shifted from providing manual services to providing advice in financial matters (Tucker, 2017). Tax planning and financial analysis have been the top priority areas in which businesses seek advice. Since gathering information from different ledgers, or even from different networks, is easy with loT technology, accountants can provide timely financial advice to their clients.

Resource: Created by using the Proceeding by Komsuoglu Yilmaz \& Boydas Hazar (2019) The Rise of Internet of Things (lot) and its Applications in Finance and accounting, Istanbul Finance Congress, November 1, 2019.

\subsection{Technology Acceptance Model (TAM)}

Technology Acceptance Model (TAM) is created by (Davis, 1989) to be able to predict users' level of acceptance for computers. In his study he added new scales for two variables as fundamental determinants of acceptance: (1) Perceived usefulness, (2) Perceived ease of use. Individuals decide to use or not to use a new technology by understanding the level of help comes from the new technology for their current job. This is called perceived usefulness. To be able to use a technology its features should also be easy to use. This variable is called perceived ease of use. In the literature many studies have been made about TAM. Some researchers (Lee, Kozar, \& Larsen, 2003) analyzed the model with an historical perspective. The others (Surendran, 2012) analyzed the model's use in the related literature. There are researchers (King \& $\mathrm{He}, 2006)$ who conducted a meta-analysis on the subject. In his study, Pavlou, (2003) analyzed technology acceptance for electronic commerce; in a very similar study $\mathrm{Ha} \&$ Stoel, (2009) examined technology acceptance of consumer on eshopping. Lu, Yu, Liu, \& Yao, (2003) have been researched on the acceptance of wireless internet by using TAM. Lin, Shih, \& Sher, (2007) added a new variable -technology readiness- to the model in their study. Walczuch, Lemmink, \& Streukens, (2007) have been tested employees' technology readiness on technology acceptance.

In some recent studies, Herrenkind, Brendel, Nastjuk, Greve, \& Kolbe, (2019) investigated end-user acceptance of autonomous electric buses to accelerate diffusion. Hamdani (2019) analyzed technology acceptance in the use of social networks by teachers and employees of education offices in Ahwaz. Rafiee \& Abbasian-Naghneh, (2019) have tested technology acceptance of e-learners in language learning.

Gao \& Bai, (2014) conducted a study on the factors influencing consumer acceptance of internet of things technology. Park, Cho, Han, \& Kwon, (2017) tested the acceptance level of smart home products. In a similar study, Kim, Park, \& Choi, (2017) analyzed technology acceptance of smart home products by using value-based adoption model.

\section{RESEARCH MODEL AND HYPOTHESES}

In the literature both Internet of Things (IOT) and Technology Acceptance Model (TAM) have a huge interest from many different disciplines. In this study, the research model proposed by Morienyane and Marnewick (2019) has been used and can be seen in Figure 1 below: 
Figure 1: Research Model

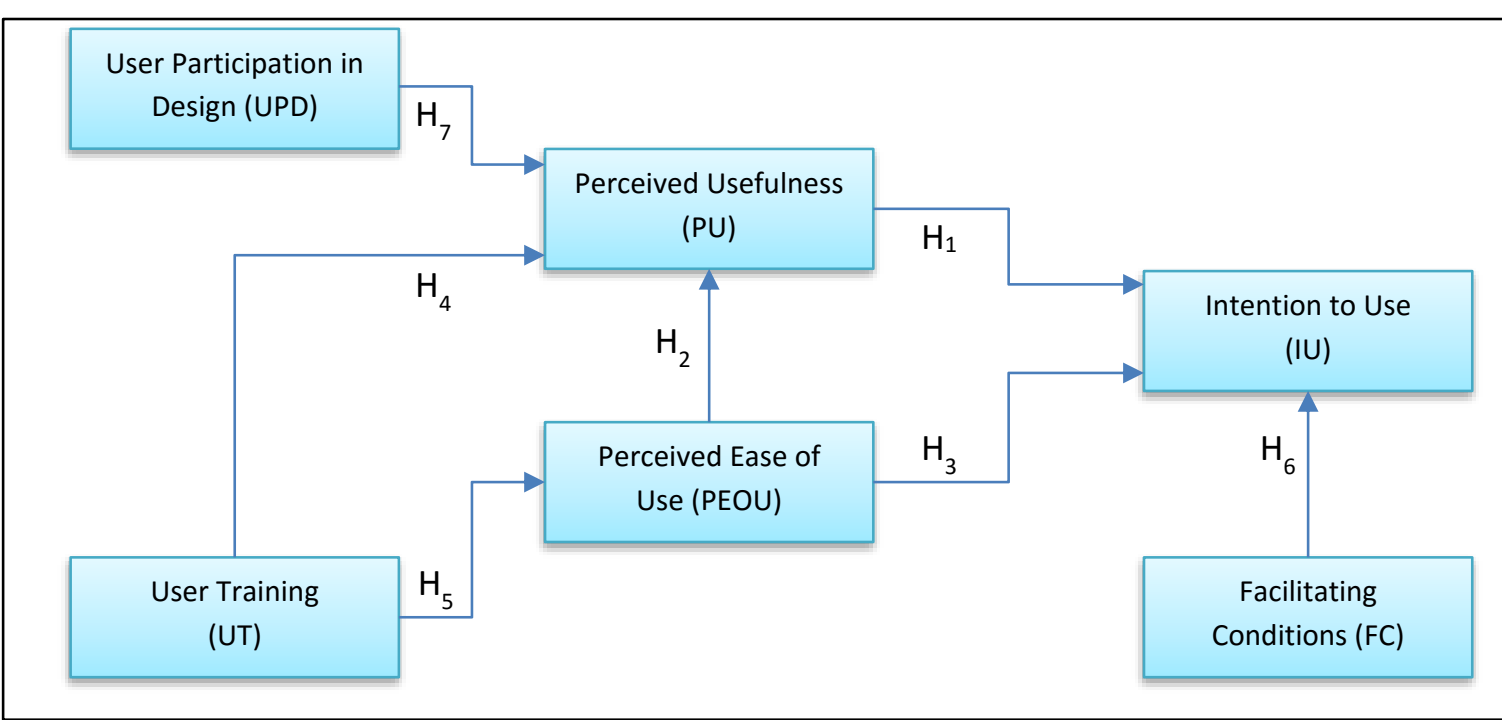

Source: Developed from Morienyane and Marnewick, (2019)

The model depicted in Figure 1 hypothesizes that when people are involved in the design of products of the related technology (UPD), they are inclined to think that these products are useful to them (PU), and thus they intend to use them (IU). Moreover, this model assumes that when people are trained to use them (UT), they tend to think that these products are useful (PU) and easy to use (PEOU), increasing the intention to use (IU). The model also states that the chance that people will use these products vastly increase if there exits facilitating conditions (FC) to use them.

According to the research model, hypotheses of the research are listed below:

$\mathrm{H}_{1}$ : There is a positive correlation between PU and IU among accounting and finance students for loT.

$\mathrm{H}_{2}$ : There is a positive correlation between PEOU and PU among accounting and finance students for loT.

$\mathrm{H}_{3}$ : There is a positive correlation between PEOU and IU among accounting and finance students for loT.

$\mathrm{H}_{4}$ : There is a positive correlation between UT and PU among accounting and finance students for loT.

$\mathrm{H}_{5}$ : There is a positive correlation between UT and PEOU among accounting and finance students for loT.

$\mathrm{H}_{6}$ : There is a positive correlation between FC and IU among accounting and finance students for loT.

$\mathrm{H}_{7}$ : There is a positive correlation between UPD and PU among accounting and finance students for loT.

\section{METHODOLOGY AND FINDINGS}

\subsection{Research Method}

In this research, a quantitative research approach has been followed by using survey method. The quintessence of survey strategy can be clarified as "addressing appropriate people on a point or subjects and afterward depicting their reactions" (Jackson, 2011).

\subsection{Sampling}

For this study, research universe can be accepted as all university students who are enrolled in accounting and finance programs in İstanbul, Turkey. This number is approximately 100.000 (23.773 seats per year). Sample size with $90 \%$ confidence interval can be calculated as 270 . Considering time as a limitation for the study, convenience sampling method has been applied to reach this number. 


\subsection{Data Collection}

A two-part questionnaire form was created for data collection. There are six demographic questions in the first part. The second part covers modified version of the questions used by Morienyane and Marnewick (2019) in their study for six scales (PU, PEOU, UT, UPD, IU, FC). 400 questionnaire forms were prepared by researchers. These forms were distributed to the students in class and collected immediately after they were filled. By this controlled approach, researchers reached 286 valid forms. SPSS program has been used to analyze the data collected via questionnaires.

\subsection{Demographical Findings}

Demographic composition of the participants is analyzed by conducting descriptive statistical analysis. Age, gender, university degree, marital status, nationality and work experience distribution of the participants can be seen in Table 4 below:

Table 4: Demographic Distribution of the Participants

\begin{tabular}{|c|c|c|c|c|c|c|c|}
\hline Variable & Options & Number & Percentage & Variable & Options & Number & Percentage \\
\hline \multirow{3}{*}{ Gender } & Male & 181 & 63.3 & \multirow{3}{*}{$\begin{array}{l}\text { Marital } \\
\text { Status }\end{array}$} & Single & 250 & 87.4 \\
\hline & Female & 103 & 36.0 & & Married & 30 & 10.5 \\
\hline & Undisclosed & 2 & 0.7 & & Undisclosed & 4 & 1.4 \\
\hline \multirow{8}{*}{ Age } & $0-17$ years old & 2 & 0.7 & \multirow{7}{*}{ Nationality } & Turkey & 80 & 28.0 \\
\hline & $\begin{array}{l}18-24 \text { years } \\
\text { old }\end{array}$ & 184 & 64.3 & & $\begin{array}{l}\text { European } \\
\text { Countries }\end{array}$ & 10 & 3.5 \\
\hline & $\begin{array}{l}25-34 \text { years } \\
\text { old }\end{array}$ & 84 & 29.4 & & Middle East & 89 & 31.1 \\
\hline & $\begin{array}{l}35-44 \text { years } \\
\text { old }\end{array}$ & 13 & 4.5 & & Asia & 47 & 16.4 \\
\hline & $\begin{array}{l}45-54 \text { years } \\
\text { old }\end{array}$ & 1 & 0.3 & & $\begin{array}{l}\text { North \& } \\
\text { South Amerika }\end{array}$ & 53 & 18.5 \\
\hline & $\begin{array}{l}55-64 \text { years } \\
\text { old }\end{array}$ & 2 & 0 & & $\begin{array}{l}\text { Australia \& } \\
\text { New Zealand }\end{array}$ & 80 & 28.0 \\
\hline & $\begin{array}{l}65-74 \text { years } \\
\text { old }\end{array}$ & 0 & 0 & & Africa & 10 & 3.5 \\
\hline & 75 and more & 0 & 0 & \multirow{4}{*}{$\begin{array}{l}\text { Work } \\
\text { Experience }\end{array}$} & $0-1$ years & 135 & 47.2 \\
\hline \multirow{3}{*}{$\begin{array}{l}\text { Enrolled } \\
\text { Program }\end{array}$} & Undergraduate & 134 & 46.9 & & $1-5$ years & 113 & 39.5 \\
\hline & Masters & 145 & 50.7 & & $5-10$ years & 22 & 7.7 \\
\hline & PhD. & 1 & 0.3 & & Over 10 years & 13 & 4.5 \\
\hline
\end{tabular}

Demographical findings of the study indicate that 2 out of 3 participants are male and most of them are single. Most of them are undergraduate and master's degree students. $28 \%$ of the participants are from Turkey and $72 \%$ of them are distributed to other countries. This demographic distribution of the participants adds an international point of view to the study.

\subsection{Reliability Tests and Factor Analysis}

For the reliability of scales in the data collected an internal measurement method (Cronbach Alpha) has been used. Cronbach Alpha (CA) is a function of the number of test items and the average inter-correlation among the items. CA value of each scale in the study can be seen in Table 5 below:

Table 5: Reliability Analysis

\begin{tabular}{|l|c|c|}
\hline Scale & Cronbach Alpha & N of Items \\
\hline PU & 0.936 & 7 \\
\hline PEOU & 0.845 & 5 \\
\hline UT & 0.833 & 3 \\
\hline UPD & 0.610 & 2 \\
\hline IU & 0.899 & 4 \\
\hline FC & 0.857 & 4 \\
\hline
\end{tabular}


For 5 out of 6 scales Cronbach alpha is more than 0.8 and only for scale UPD it is 0.61 . Since reliability values between 0.6 to 0.7 are acceptable in exploratory research (Nunnally \& Bernstein, 1994), all scales of the study can be accepted as reliable.

\subsection{Hypotheses Testing}

To test the hypotheses, same statistical path is followed as the study of Morienyane and Marnewick, (2019). To test the hypotheses, Pearson's correlation coefficient test has been conducted. Results of the test can be seen in Table 6:

Table 6: Pearson's Correlation Coefficient

\begin{tabular}{|ll|r|r|r|r|r|r|}
\hline & & PUORT & IUORT & PEOUORT & FCORT & \multicolumn{1}{c|}{ UTORT } & UPDORT \\
\hline PUORT & Pearson Correlation & 1 & $.765^{* *}$ & $.729^{* *}$ & $.694^{* *}$ & $.689^{* *}$ & $.604^{* *}$ \\
& Sig. (2-tailed) & & .000 & .000 & .000 & .000 & .000 \\
& $\mathrm{~N}$ & 286 & 286 & 286 & 286 & 286 & 286 \\
\hline IUORT & Pearson Correlation & $.765^{* *}$ & 1 & $.698^{* *}$ & $.770^{* *}$ & $.766^{* *}$ & $.638^{* *}$ \\
& Sig. (2-tailed) & .000 & & .000 & .000 & .000 & .000 \\
& $\mathrm{~N}$ & 286 & 286 & 286 & 286 & 286 & 286 \\
\hline PEOUORT & Pearson Correlation & $.729^{* *}$ & $.698^{* *}$ & 1 & $.675^{* *}$ & $.651^{* *}$ & $.580^{* *}$ \\
& Sig. (2-tailed) & .000 & .000 & & .000 & .000 & .000 \\
& $\mathrm{~N}$ & 286 & 286 & 286 & 286 & 286 & 286 \\
\hline FCORT & Pearson Correlation & $.694^{* *}$ & $.770^{* *}$ & $.675^{* *}$ & 1 & $.760^{* *}$ & $.650^{* *}$ \\
& Sig. (2-tailed) & .000 & .000 & .000 & & .000 & .000 \\
& $\mathrm{~N}$ & 286 & 286 & 286 & 286 & 286 & 286 \\
\hline UTORT & Pearson Correlation & $.689^{* *}$ & $.766^{* *}$ & $.651^{* *}$ & $.760^{* *}$ & .000 & $.673^{* *}$ \\
& Sig. (2-tailed) & .000 & .000 & .000 & .000 & .000 \\
& $\mathrm{~N}$ & 286 & 286 & 286 & 286 & 286 & 286 \\
\hline UPDORT & Pearson Correlation & $.604^{* *}$ & $.638^{* *}$ & $.580^{* *}$ & $.650^{* *}$ & $.673^{* *}$ & .000 \\
& Sig. (2-tailed) & .000 & .000 & .000 & .000 & 286 & 286 \\
& $\mathrm{~N}$ & 286 & 286 & 286 & 286 & 286 \\
\hline
\end{tabular}

**. Correlation is significant at the 0.01 level (2-tailed).

Pearson's Correlation Test results indicate that there is a positive correlation between PU and IU. This means that if accounting and finance students perceive loT as useful (PU), they probably intend to use it (IU). Perceived ease of use (PEOU) will also positively affect perceived usefulness (PU) and intention to use (IU). User training (UT) will provide more knowledge on the subject and facilitate both perceived ease of use (PEOU) and perceived usefulness (PU). If conditions will be facilitated (FC) it will also create a positive effect on the intention (IU). Finally, if users can participate in the design of the loT enabled products (UPD), it will create a positive impact on perceived usefulness (PU).

In Table 7 below, a summary of hypotheses tested in the study can be seen.

Table 7: Summary of the Hypotheses Tests

\begin{tabular}{|l|l|c|}
\hline $\mathbf{H}_{\mathbf{N}}$ & Hypothesis & Accepted/Rejected \\
\hline $\mathrm{H}_{1}$ & There is a positive correlation between PU and IU among accounting and finance students for loT. & ACCEPTED \\
\hline $\mathrm{H}_{2}$ & There is a positive correlation between PEOU and PU among accounting and finance students for loT. & ACCEPTED \\
\hline $\mathrm{H}_{3}$ & There is a positive correlation between PEOU and IU among accounting and finance students for loT. & ACCEPTED \\
\hline $\mathrm{H}_{4}$ & There is a positive correlation between UT and PU among accounting and finance students for loT. & ACCEPTED \\
\hline $\mathrm{H}_{5}$ & There is a positive correlation between UT and PEOU among accounting and finance students for loT. & ACCEPTED \\
\hline $\mathrm{H}_{6}$ & There is a positive correlation between FC and IU among accounting and finance students for loT. & ACCEPTED \\
\hline $\mathrm{H}_{7}$ & There is a positive correlation between UPD and PU among accounting and finance students for loT. & ACCEPTED \\
\hline
\end{tabular}

\section{CONCLUSION, LIMITATIONS AND RECOMMENDATIONS}

The purpose of this study was to test technology acceptance model for internet of things (IoT) among accounting and finance students. Since loT has a wide area of use in Finance and Accounting, its acceptance level is important between accounting and finance students. 
Internet of things refers the interconnection between devices via internet including mechanical and digital objects. The advancements including internet, wireless communication, microelectromechanical systems (MEMS) and radio frequency identification (RFID) created a world of interconnected devices; with loT this interconnection covers everyday objects. In this study it is examined the areas where loT can be used to facilitate finance and accounting. User training both facilitates the ease of use and usefulness perception and indirectly affects the intention. At the same time, if conditions can be facilitated, this will also make a positive effect on the intention. These results indicate that accounting and finance students are ready to accept the new technological advancements in loT and implement it to their prospective jobs.

Internet of things (IOT) technology has a wide range of use within industrial practitioners and academic researchers. Today, the importance of internet of things is increasing day by day. Each day new types of loT enabled devices take their place in the market.

Results of this study indicate that between accounting and finance students, perception on ease of use and usefulness have a positive impact on their intention to use the technology. Cooperation in the design of the technology positively affects its usefulness perception. Ease of use perception has also a positive effect of the usefulness perception.

Financial technologies, IoT and Al integration and collaboration in many disciplines will create more accurate and faster jobs and reduce all types of costs by controlling production, maintenance, logistics and many other business functions. The customer satisfaction and loyalty will be positively affected by these advancements. Finance and accounting, which are the two main functions of businesses, will be changed forever with the help of loT. Therefore, understanding the readiness level of the future users and managers is very important. Analyzing their technology acceptance in loT gives this study a high level of importance.

Primary limitation of the study is its coverage of only two business disciplines: accounting and finance. Second limitation of the study is its research universe and sample. The study only covers future potential corporate loT users and managers: accounting and finance students.

In the future researches and studies, researchers and professionals may study different business functions or different areas of loT use. Also for further researches, different variables like Artificial Intelligence can be added. Both researchers and practitioners in accounting and finance disciplines should give greater importance to loT to be able to benefit from its unexplored opportunities.

\section{REFERENCES}

Ashton, K. (2009). That 'internet of things' thing. RFID Journal. Available at: http://www.rfidjournal.com/article/print/4986 https://www.rfidjournal.com/articles/view?4986 http://www.rfidjournal.com/article/print/4986

Balakarthiga M, (2018). Top 7 Applications of IoT For Business. [online] Available at: [https://scrape.works/blog/top-7-applications-of-iotin-business/] [Accessed 23.10.2019].

Barreto, L., Amaral, A., \& Pereira, T. (2017). Industry 4.0 implications in logistics: an overview. Procedia Manufacturing. https://doi.org/10.1016/j.promfg.2017.09.045

Ben-Daya, M., Hassini, E., \& Bahroun, Z. (2017). Internet of things and supply chain management: a literature review. International Journal of Production Research. https://doi.org/10.1080/00207543.2017.1402140

Bi, Z., Xu, L. D., \& Wang, C. (2014). Internet of things for enterprise systems of modern manufacturing. IEEE Transactions on Industrial Informatics. https://doi.org/10.1109/TII.2014.2300338

Buyya, R., \& Dastjerdi, A. V. (2016). Internet of Things: Principles and Paradigms. Internet of Things: Principles and Paradigms. https://doi.org/10.1016/C2015-0-04135-1

Caro, F., \& Sadr, R. (2019). The Internet of Things (loT) in retail: Bridging supply and demand. Business Horizons. https://doi.org/10.1016/j.bushor.2018.08.002

Chandi, N., (2017). The Internet Of Things For Accountants. Forbes Now. [online] Available at: [https://www.forbes.com/sites/forbestechcouncil/2017/03/27/the-internet-of-things-for-accountants/\#30720d0a445b] [Accessed 17 October 2019].

Davis, F. D. (1989). Perceived usefulness, perceived ease of use, and user acceptance of information technology. MIS Quarterly: Management Information Systems. https://doi.org/10.2307/249008

Digiteum (2019). How loT is Changing Financial Services and Banking [online] Available at: [https://www.digiteum.com/internet-of-thingsbanking-finances/] [Accessed 28.10.2019]. 
Dorey, P. (2017). Securing the internet of things. In Smart Cards, Tokens, Security and Applications: Second Edition. https://doi.org/10.1007/978-3-319-50500-8_16

Gao, L., \& Bai, X. (2014). A unified perspective on the factors influencing consumer acceptance of internet of things technology. Asia Pacific Journal of Marketing and Logistics. https://doi.org/10.1108/APJML-06-2013-0061

Gürün F. (2019) Endüstri 4.0 ve Beşeri Sermayenin Geleceği, Sosyal Siyaset Konferansları Dergisi/Journal of Social Policy Conferences, 76: 67-88.

Ha, S., \& Stoel, L. (2009). Consumer e-shopping acceptance: Antecedents in a technology acceptance model. Journal of Business Research. https://doi.org/10.1016/j.jbusres.2008.06.016

Haddud, A., DeSouza, A., Khare, A., \& Lee, H. (2017). Examining potential benefits and challenges associated with the Internet of Things integration in supply chains. Journal of Manufacturing Technology Management. https://doi.org/10.1108/JMTM-05-2017-0094

Haller, S., Karnouskos, S., \& Schroth, C. (2009). The Internet of things in an enterprise context. In Lecture Notes in Computer Science (including subseries Lecture Notes in Artificial Intelligence and Lecture Notes in Bioinformatics). https://doi.org/10.1007/978-3-642-0098532

Hamdani, M. (2019). Technology Acceptance in the Use of Social Networks by Teachers and Employees of Education Offices in Ahwaz. Turkish Online Journal of Educational Technology - TOJET.

Hasselblatt, M., Huikkola, T., Kohtamäki, M., \& Nickell, D. (2018). Modeling manufacturer's capabilities for the Internet of Things. Journal of Business and Industrial Marketing. https://doi.org/10.1108/JBIM-11-2015-0225

Herrenkind, B., Brendel, A. B., Nastjuk, I., Greve, M., \& Kolbe, L. M. (2019). Investigating end-user acceptance of autonomous electric buses to accelerate diffusion. Transportation Research Part D: Transport and Environment. https://doi.org/10.1016/j.trd.2019.08.003

Jackson, S.L. (2011) "Research Methods and Statistics: A Critical Approach", 4th edition, Cengage Learning, p.17

Jing, Q., Vasilakos, A. V., Wan, J., Lu, J., \& Qiu, D. (2014). Security of the Internet of Things: perspectives and challenges. Wireless Networks. https://doi.org/10.1007/s11276-014-0761-7

Kim, Y., Park, Y., \& Choi, J. (2017). A study on the adoption of IoT smart home service: using Value-based Adoption Model. Total Quality Management and Business Excellence. https://doi.org/10.1080/14783363.2017.1310708

King, W. R., \& He, J. (2006). A meta-analysis of the technology acceptance model. Information and Management. https://doi.org/10.1016/j.im.2006.05.003

Komsuoglu Yilmaz N. \& Boydas Hazar H. (2019) The Rise of Internet Of Things (lot) And Its Applications In Finance And Accounting, Istanbul Finance Congress, November 1, 2019

Kumar, Dr \& Raza, Z. (2017). Internet of Things: Possibilities and Challenges. International Journal of Systems and Service-Oriented Engineering. 7. 32-52. 10.4018/IJSSOE.2017070103.

Lee, I., \& Lee, K. (2015). The Internet of Things (IoT): Applications, investments, and challenges for enterprises. Business Horizons. https://doi.org/10.1016/j.bushor.2015.03.008

Lee, Y., Kozar, K. A., \& Larsen, K. R. T. (2003). The Technology Acceptance Model: Past, Present, and Future. Communications of the Association for Information Systems. https://doi.org/10.17705/1cais.01250

Lin, C. H., Shih, H. Y., \& Sher, P. J. (2007). Integrating technology readiness into technology acceptance: The TRAM model. Psychology and Marketing. https://doi.org/10.1002/mar.20177

Löffler, M., \& Tschiesner, A. (2013). The Internet of Things and the future of manufacturing. McKinsey on Business Technology. https://doi.org/10.1201/b19296-12

Lu, J., Yu, C. S., Liu, C., \& Yao, J. E. (2003). Technology acceptance model for wireless Internet. Internet Research. https://doi.org/10.1108/10662240310478222

Macaulay, J., Buckalew, L., \& Chung, G. (2015). Internet of Things in Logistics. DHL Trend Research.

Mathaba, S., Adigun, M., Oladosu, J., \& Oki, O. (2017). On the use of the Internet of Things and Web 2.0 in inventory management. In Journal of Intelligent and Fuzzy Systems. https://doi.org/10.3233/JIFS-169252

Morienyane L. \& Marnevick A. (2019) Technology Acceptance Model of Internet of Things for Water Management at a local municipality, IEEE Technology \& Engineering Management Conference (TEMSCON)

Nunnally, J.C. and Bernstein, I.H. (1994) The Assessment of Reliability. Psychometric Theory, 3, 248-292. 
Park, E., Cho, Y., Han, J., \& Kwon, S. J. (2017). Comprehensive Approaches to User Acceptance of Internet of Things in a Smart Home Environment. IEEE Internet of Things Journal. https://doi.org/10.1109/JIOT.2017.2750765

Pavlou, P. A. (2003). Consumer acceptance of electronic commerce: Integrating trust and risk with the technology acceptance model. International Journal of Electronic Commerce. https://doi.org/10.1080/10864415.2003.11044275

Perera, C., Liu, C. H., Jayawardena, S., \& Chen, M. (2015). A Survey on Internet of Things from Industrial Market Perspective. IEEE Access. https://doi.org/10.1109/ACCESS.2015.2389854

Rafiee, M., \& Abbasian-Naghneh, S. (2019). E-learning: development of a model to assess the acceptance and readiness of technology among language learners. Computer Assisted Language Learning. https://doi.org/10.1080/09588221.2019.1640255

Rathore, H., (2019). How Will loT Impact the Accounting and Billing System? DZone. [online] Available at: [https://dzone.com/articles/how-iot-will-impact-the-accounting-and-billing-sys] [Accessed 20 October 2019].

Riahi Sfar, A., Natalizio, E., Challal, Y., \& Chtourou, Z. (2018). A roadmap for security challenges in the Internet of Things. Digital Communications and Networks. https://doi.org/10.1016/j.dcan.2017.04.003

Samaila, M. G., Neto, M., Fernandes, D. A. B., Freire, M. M., \& Inácio, P. R. M. (2017). Security challenges of the Internet of Things. In Internet of Things. https://doi.org/10.1007/978-3-319-50758-3_3

Shariatzadeh, N., Lundholm, T., Lindberg, L., \& Sivard, G. (2016). Integration of Digital Factory with Smart Factory Based on Internet of Things. In Procedia CIRP. https://doi.org/10.1016/j.procir.2016.05.050

Sicari, S., Rizzardi, A., Grieco, L. A., \& Coen-Porisini, A. (2015). Security, privacy and trust in Internet of things: The road ahead. Computer Networks. https://doi.org/10.1016/j.comnet.2014.11.008

Stankovic, J. A. (2014). Research directions for the internet of things. IEEE Internet of Things Journal. https://doi.org/10.1109/JIOT.2014.2312291

Storey, H. (2014). Industrial internet of things. In ISA Process Control and Safety Symposium 2014, PCS 2014.

Sun, C. (2012). Application of RFID Technology for Logistics on Internet of Things. AASRI Procedia. https://doi.org/10.1016/j.aasri.2012.06.019

Suo, H., Wan, J., Zou, C., \& Liu, J. (2012). Security in the internet of things: A review. In Proceedings - 2012 International Conference on Computer Science and Electronics Engineering, ICCSEE 2012. https://doi.org/10.1109/ICCSEE.2012.373

Surendran, P. (2012). Technology Acceptance Model : A Survey of Literature. International Journal of Business and Social Research.

Tan, L., \& Wang, N. (2010). Future internet: The Internet of Things. Proceedings of the 3rd International Conference on Advanced Computer Theory and Engineering (ICACTE).

Tjahjono, B., Esplugues, C., Ares, E., \& Pelaez, G. (2017). What does Industry 4.0 mean to Supply Chain? Procedia Manufacturing. https://doi.org/10.1016/j.promfg.2017.09.191

Tucker, A., (2017). How the loT will impact the accounting sector. Accountants Daily. [online] Available at: [https://www.accountantsdaily.com.au/columns/10279-how-the-iot-will-impact-the-accounting-sector] [Accessed 20 October 2019].

Verdouw, C. N., Wolfert, J., Beulens, A. J. M., \& Rialland, A. (2016). Virtualization of food supply chains with the internet of things. Journal of Food Engineering. https://doi.org/10.1016/j.jfoodeng.2015.11.009

Walczuch, R., Lemmink, J., \& Streukens, S. (2007). The effect of service employees' technology readiness on technology acceptance. Information and Management. https://doi.org/10.1016/j.im.2006.12.005

Weber, R. H. (2010). Internet of Things - New security and privacy challenges. Computer Law and Security Review. https://doi.org/10.1016/j.clsr.2009.11.008

Weinberg, B. D., Milne, G. R., Andonova, Y. G., \& Hajjat, F. M. (2015). Internet of Things: Convenience vs. privacy and secrecy. Business Horizons. https://doi.org/10.1016/j.bushor.2015.06.005

Willner, A. (2018). The Industrial Internet of Things. In Internet of Things A to Z. https://doi.org/10.1002/9781119456735.ch11

Xu, Y., \& Chen, M. (2016). Improving Just-in-Time Manufacturing Operations by Using Internet of Things Based Solutions. In Procedia CIRP. https://doi.org/10.1016/j.procir.2016.10.030

Zhao, K., \& Ge, L. (2013). A survey on the internet of things security. In Proceedings - 9th International Conference on Computational Intelligence and Security, CIS 2013. https://doi.org/10.1109/CIS.2013.145

Zhou, L., Chong, A. Y. L., \& Ngai, E. W. T. (2015). Supply chain management in the era of the internet of things. International Journal of Production Economics. https://doi.org/10.1016/j.ijpe.2014.11.014 